Iterations of Loss 


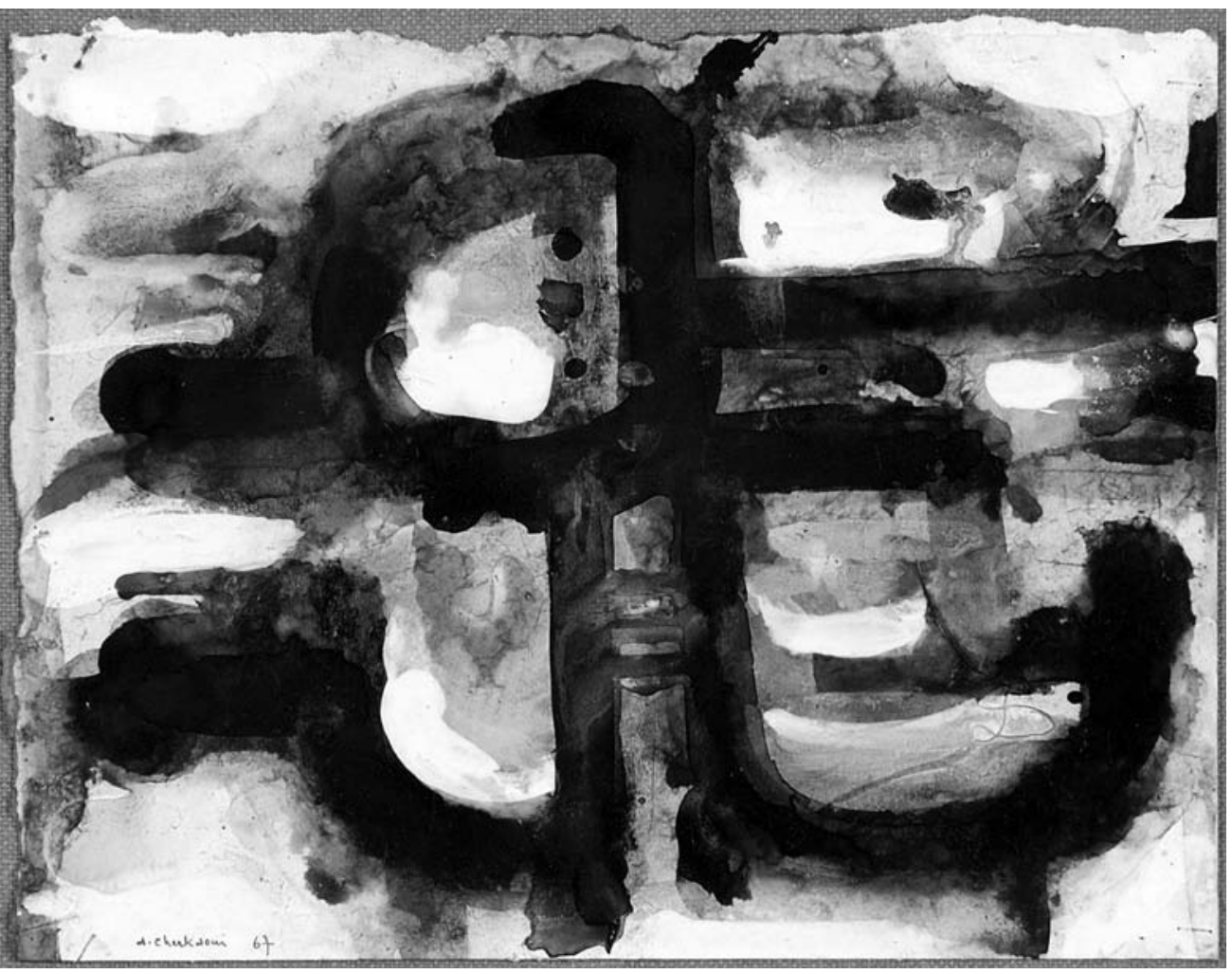




\section{Iterations of Loss}

MUTILATION AND AESTHETIC FORM, AL-SHIDYAQ TO DARWISH

Jeffrey Sacks

FORDHAM UNIVERSITY PRES New York 2015 


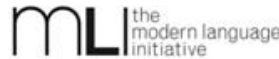

THIS BOOK IS MADE POSSIBLE BY A COLLABORATIVE GRANT

FROM THE ANDREW W. MELLON FOUNDATION.

\section{Copyright () 2015 Fordham University Press}

All rights reserved. No part of this publication may be reproduced, stored in a retrieval system, or transmitted in any form or by any means-electronic, mechanical, photocopy, recording, or any other-except for brief quotations in printed reviews, without the prior permission of the publisher.

Visit us online at www.fordhampress.com.

The image of the painting by Ahmed Cherkaoui that appears as a frontispiece to this book and on its cover is reproduced with the permission of Hassan Ezzaim, Director of Fondation ONA (Rabat).

Passages that appear in Chapters I, 2, and 3 of this book have been published in diacritics 37.4 (2007) and are reproduced here with the permission of Johns Hopkins University Press. Portions of Chapter 3 have been published in an article, "Falling into Pieces, Or Ahmad Faris al-Shidyaq and Literary History: A Love Letter" (Middle Eastern Literatures I6.3 [2013]), and are reproduced here with the permission of $\odot$ Taylor and Francis. The article may be accessed on line at the following address: http://www. tandfonline.com/doi/full/IO.I080/I475262X.2013.891392\#.U77w2UDPYZQ.

Fordham University Press has no responsibility for the persistence or accuracy of URLs for external or third-party Internet websites referred to in this publication and does not guarantee that any content on such websites is, or will remain, accurate or appropriate.

Fordham University Press also publishes its books in a variety of electronic formats. Some content that appears in print may not be available in electronic books.

Library of Congress Cataloging-in-Publication Data

Sacks, Jeffrey.

Iterations of loss : mutilation and aesthetic form, Al-Shidyaq to Darwish / Jeffrey

Sacks. - First edition.

pages $\mathrm{cm}$

Includes bibliographical references and index.

ISBN 978-0-8232-6494-o (cloth : alk. paper)

ISBN 978-0-8232-6495-7 (pbk. : alk. paper)

I. Psychic trauma in literature. 2. Violence in literature. 3. Arab-Israeli conflict-

Literature and the conflict. 4. Arabic literature-19th century-History and criticism. 5. Arabic literature-2oth century-History and criticism. 6. Hebrew literature-20th century-History and criticism. I. Title.

$\mathrm{PJ}_{75}$ I9.P $78 \mathrm{~S}_{33} 20 \mathrm{I} 4$

892.7 'O9-dc23

2014030502

Printed in the United States of America

I7 I6 I5 5432 I

First edition 
for Leah, Leila, Bella 
This page intentionally left blank 